\title{
CHEMICAL CHANGES OF SOIL AND WATER IN HILLSIDE AREAS UNDER INTENSIVE HORTICULTURE
}

\author{
Laércio S. Silva ${ }^{1 *}$, Izabel C. de L. Galindo², Romário P. Gomes ${ }^{3}$, Milton C. C. Campos ${ }^{4}$, \\ Edivan R. de Souza ${ }^{2}$, José M. da Cunha ${ }^{4}$
}

${ }^{1 *}$ Corresponding author. Universidade do Estado de São Paulo - UNESP/ Jaboticabal - SP, Brasil.

E-mail: laerciosantos18@gmail.com

\section{KEYWORDS \\ landscape, environmental contamination, management practices, irrigation water.}

\begin{abstract}
Inadequate and intensive management of soils can promote changes in their chemical attributes and impair the quality of surface and groundwater, especially in hillside areas. Therefore, the aim of this study was to identify possible changes in soil and water chemical composition of hillside areas cultivated with horticulture. For this, chemical attributes of three soil depths $(0-10,10-30$, and 30-60 cm) were determined in three hillside positions (upper, middle, and lower thirds) of five hillside and adjacent forest areas, as well as water from reservoirs for agricultural use and human consumption. Compared with the forest area, horticultural areas present soil with lower organic matter content and $\mathrm{CEC}$, but higher values of $\mathrm{pH}$, base saturation, and contents of $\mathrm{P}, \mathrm{Ca}$, and $\mathrm{K}$. In cultivated areas, CEC decreases from the upper to the lower hillside, without significant changes in other soil fertility parameters. Soil fertility decreases with depth, regardless of soil management and hillside position. Water from reservoirs adjacent to hillside areas with horticulture is more acidic and has a higher nitrate content, especially during rainy periods.
\end{abstract}

\section{INTRODUCTION}

Soil and water are essential resources for human life survival, but their intensive and inadequate use has led to environmental degradation (Chartres \& Noble, 2015). Hillside areas are especially susceptible to degradation, mainly when used for olericulture due to an intensive soil management and use of agricultural inputs in this activity (Lima et al., 2015; 2016). There are reports that the lower the technological level of agriculture is, the greater the potential for degrading the agricultural environment (Stefanoski et al., 2013). Practices involving poor soil cover and its tillage favor environment deterioration, both in conventional and organic agriculture (Santos et al., 2010).

The dynamics and intensity of erosive processes are influenced by landscape form (relief) (Qi et al., 2012) by directing the flows of water and sediments. Thus, while erosion is influenced by landscape form, different directions of water flow are responsible for variations of chemical and physical attributes over the hillside (Sanchez et al., 2009). In addition to influencing the drainage of a river basin, relief also determines the occurrence of plant species and land use capacity. The removal of natural vegetation for agricultural use, especially for crops that require an intensive management, may result in loss of nutrients along the slope, especially when management is inadequate (Faria et al., 2010).

Several studies of soil-landscape relationships have identified that intensive and continuous cultivation in convex areas (on hillsides) present progressive sediment losses, while concave areas act as deposition areas (Marques Júnior et al., 2014; Resende et al., 2014). In this regard, Campos et al. (2013) investigated the influence of relief on soil attribute distribution in the segment of a hillside and found an increase in the contents of $\mathrm{P}, \mathrm{Ca}, \mathrm{Mg}$, and $\mathrm{K}$ and values of $\mathrm{pH}$ and CEC starting from the hilltop towards the softer slope of the relief, i.e. in areas of deposition foothills. In addition, soil type, climate, vegetation, management, and the technological level of farms influence the distribution of soil chemical attributes

\footnotetext{
${ }^{2}$ Universidade Federal Rural de Pernambuco - UFRPE/ Recife - PE, Brasil.

${ }^{3}$ Universidade do Estado de São Paulo - UNESP/ Jaboticabal - SP, Brasil.

${ }^{4}$ Universidade Federal do Amazonas - UFAM/ Humaitá - AM, Brasil.

Received in: 5-16-2017

Accepted in: 4-9-2018
} 
along the landscape of a river basin (Sanchez et al., 2009; Campos et al., 2013).

In agricultural areas where the highest technological level is employed, the occurrence of highfertility soils is common because the nutrients exported by harvests are replenished and the adoption of conservation management practices minimize erosion and leach losses (Portugal et al., 2010). In this scenario, Camocim de São Félix stands out for the irrigated cultivation of vegetables and use of high amounts of fertilizers and phytosanitary products to maintain crop productivity. Associated with this, the rather rugged (concave-convex) relief and inadequate management of these areas lead to large losses of nutrients, which accumulate in the lower parts of the river basin, usually in dams or reservoirs, being the main cause of eutrophication of the water used for irrigating vegetables and human and animal consumption.

The use of multivariate analysis in agrarian sciences has allowed a better assessment of changes imposed on the chemical quality of soil and water (Oliveira et al., 2008; Coletti et al., 2010) since the conventional statistical analysis is often not sufficient to describe cause-and-effect relationships (Silva et al., 2016). By means of the factor and principal components analyses, Coletti et al. (2010) concluded that substances of ammonia, ammoniacal nitrogen, and nitrate from agricultural activities were the main contaminants of water resources. In the study of Silva et al. (2016), the application of these analyses not only discriminated the enrichment sources of OM, P, and heavy metals in vegetable cultivation but also elected and revealed the decisive factor for distributing these variables along the hillside of an Oxisol. In short, multivariate statistics allows a greater capacity to describe intra- and interdependence relationships in agricultural systems, allowing establishing and planning more appropriate management practices.
Although olericulture is one of the agricultural activities that intensely exploit soil and water and use agricultural inputs (Lima et al., 2016), there is a lacuna in the literature concerning its effects on soil and water changes of surface and ground sources, especially in hillside areas of river basins. In order to verify the hypothesis that the olericulture with a low technological level developed in a hillside environment can induce great changes in these environments, this study aimed to identify changes in soil and water chemical attributes of hillside areas under intensive horticulture.

\section{MATERIAL AND METHODS}

Soil and reservoir water samples were selected from five vegetable growing areas located in Camocim de São Félix, Pernambuco, Brazil (Figure 1). Regional climate is type $\mathrm{As}^{\prime}$, i.e. a rainy tropical climate with a dry summer according to Alvares et al. (2013) classification. The average annual temperature is around $24^{\circ} \mathrm{C}$, with an annual precipitation ranging from 900 to $1,300 \mathrm{~mm}$. Altitudes rarely exceed $1000 \mathrm{~m}$, with a wavy and rather rugged relief, very to moderately developed, deep soils, and natural vegetation predominantly of semideciduous and/or semi-evergreen forests (BRASIL, 1973).

Selection of areas was carried out based on in loco visits and information obtained from the local office of the Instituto Agronômico de Pernambuco (IPA) and farmers. Thus, we selected five agricultural areas (A1, A2, A3, A4, and A5), with a typical regional management system, and four forest areas (F1, F2, F3, and F4), which consisted of fragments of secondary forest vegetation at the hilltop, with the minimum of anthropogenic intervention, and used as reference areas to better express the results of the management effect on cultivated areas.

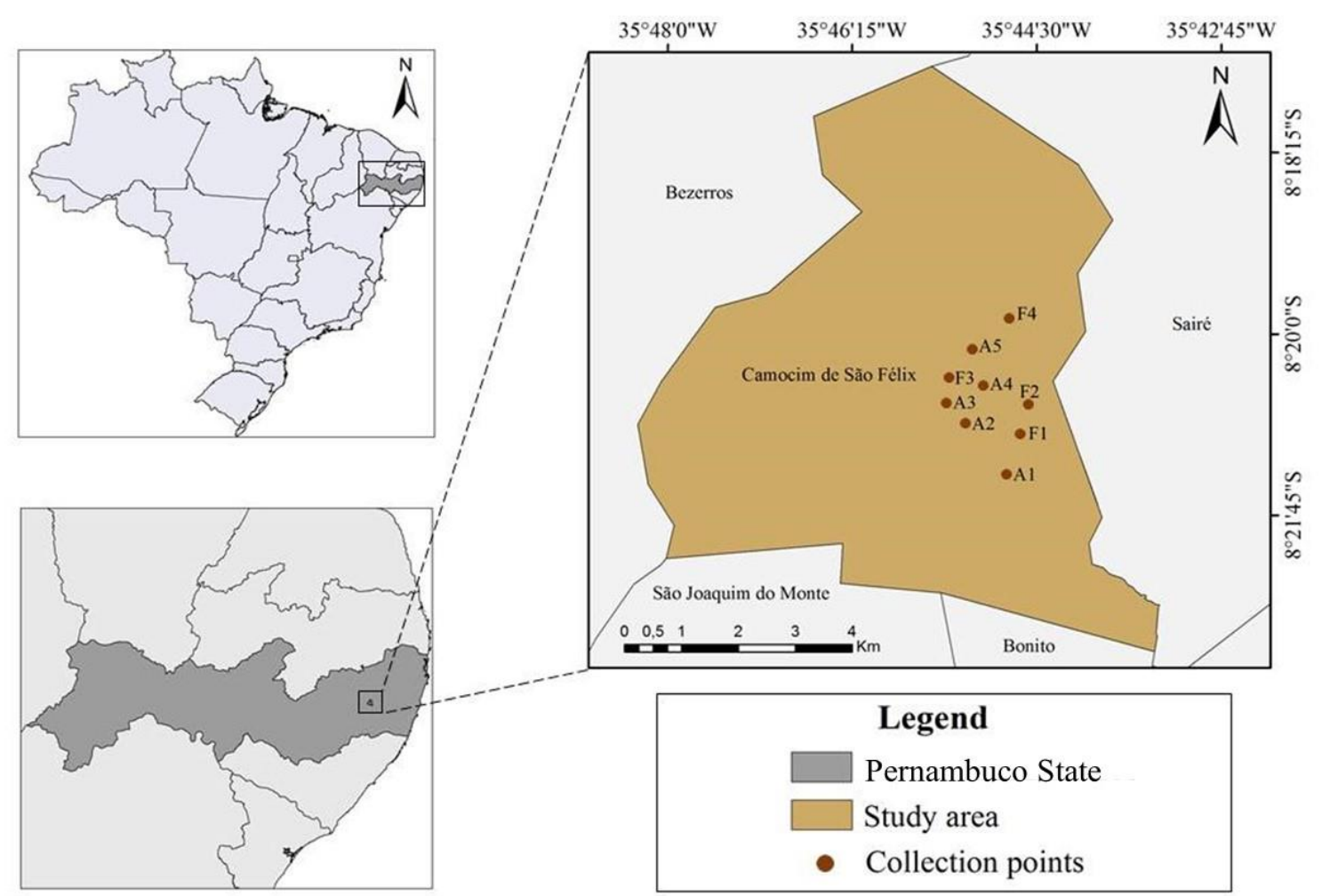

FIGURE 1. Location of agricultural (A1, A2, A3, A4, and A5) and native forest (F1, F2, F3, and F4) areas. 
At the different sampling sites, the soil is classified as a Yellow Latosol (EMBRAPA, 2013), which corresponds to a Xanthic Ferralsol according to FAO (1990) classification, developed from gneiss and granite rocks of the Pre-Cambrian period (BRASIL, 1973). The soil is exploited successively throughout the year by growing the main vegetables: tomatoes, cabbage, chard, lettuce, peppers, and cowpeas. Vegetable cultivation in these areas is characterized by planting in short grooves in beds or pits where seeds and/or seedlings are placed.

Soil fertilization is always performed by adding organic material (poultry litter) and chemical fertilizers. Crop management consists of sprinkler and localized irrigation (micro-sprinkler and drip), as well as fertilizer and pesticide applications in a preventive and corrective way most of the times without a technical support. Among the fertilizers historically used during a 35-year cultivation, the following stand out: monoammonium phosphate (MAP), diammonium phosphate (DAP), simple superphosphate, urea, NPK formulations (06-24-12, 2010-20, 10-10-10, 10-20-20, and 20-0-20), potassium chloride, potassium sulfate, micronutrients (FTE), foliar fertilizers (Zn), ammonium sulfate, calcium nitrate, and potassium nitrate.

In the cultivated areas, soil samples were collected in the planting rows, totaling 10 simple samples for each composite sample at each hillside position (upper third UT, middle third or hillside - MT, and lower third or foothill - LT ) and three depths (0-10 cm, 10-30 cm, and 30-60 cm). In forest areas (F), sampling was carried out in a zigzag pattern only at the top, being collected 10 simple samples to form a composite sample, also at the three depths. These samples, after air-drying, were decloded and sieved through a $2-\mathrm{mm}$ opening nylon sieve.

In the irrigation water reservoirs (R1, R2, R3, R4, and $\mathrm{R} 5$ ) of the respective cultivated areas and in the reservoir for human consumption (R6), $200 \mathrm{~mL}$ of water was collected between the 5th and 8th days of all months of 2010. To obtain representative samples, subsamples were collected at different points of the dams, avoiding sites with atypical turbidity or suspended material. After collection, samples passed through qualitative filter paper of slow filtration, being conditioned in a refrigerator $\left(4{ }^{\circ} \mathrm{C}\right)$ and then analyzed. In addition, monthly precipitation data were obtained from ITEP/LAMEPE (2010), being used to assist in interpreting the results.

In soil samples, we determined the $\mathrm{pH}$ and contents of $\mathrm{Ca}, \mathrm{Mg}, \mathrm{K}, \mathrm{H}+\mathrm{Al}, \mathrm{P}$, organic carbon, and $\mathrm{Al}$ (EMBRAPA, 1997). From the obtained data, we calculated the sum of bases (SB), cation exchange capacity (CEC), base saturation $(\mathrm{V})$, and organic matter $(\mathrm{OM})$. In water samples, on the other hand, we determined the $\mathrm{pH}, \mathrm{P}$ (vanado-molybdate colorimetry), $\mathrm{NO}_{3}{ }^{-}$, and $\mathrm{K}^{+}$, determined by flame photometry.

The results were submitted to analysis of variance by the F-test in a randomized block design, with the five areas considered as blocks. The three hillside positions of the cultivation areas (upper, middle, and lower thirds) + forest (4 positions), combined with the three layers of soil sampling, composed the 12 treatments, which were analyzed statistically in a $4 \times 3$ factorial scheme. The means of soil chemical attributes were compared by the Tukey's test at 1 and 5\% probability. Pearson correlations were also carried out among soil chemical attributes at 5 and $1 \%$ probability.

The dependence structure among variables was investigated by principal component analysis, which is an exploratory multivariate technique that projects the original information into a smaller set of latent variables, which are the eigenvectors constructed with eigenvalues extracted from the covariance matrix, preserving the maximum of the original relevant information. After standardizing the variables (chemical attributes, OM, cultivation areas, landscape segments, and depths) to zero mean and unit variance, the criterion adopted to select the number of components was eigenvalues above 1.00, as proposed by Kaiser (1958). All statistical analyses were processed in the software Statistica 7.0.

\section{RESULTS AND DISCUSSION}

The results of the F-test for the interaction between positions + forest on the hillside and depths were only significant $(p<0.05)$ for soil $K$ content (Table 1$)$. This indicates that, except for $\mathrm{K}$, soil position in the hillside and depth had independent influences on soil chemical attributes.

Soil position was the only significant factor $(\mathrm{P}<0.01)$ regarding $\mathrm{pH}$ values (Table 1$)$, which were similar in the three landscape positions. However, $\mathrm{pH}$ values were higher when compared to forest soils, corroborating the results of Santos et al. (2010) and Guareschi et al. (2014). This fact may be associated with the immobilization of bases in a greater diversity of plants, as well as for larger sized plants that predominate in the forest (Guareschi et al., 2014). In fact, the results showed that the forest soil had the lowest $\mathrm{Ca}$ and $\mathrm{K}$ contents, which reflected in lower base saturation (V) when compared to soil values of the three hillside positions cultivated with horticulture (Table 1). Soil base saturation of the three hillside positions is at the level considered from medium to high, while in the forest, it is considered from low to very low (Faria et al., 2007). 
TABLE 1. Average values of chemical attributes at different depths of a Yellow Latosol under original forest and in the upper (UT), medium (MT), and lower (LT) thirds of the hillside in five olericulture areas in Camocim de São Felix, PE, Brazil.

\begin{tabular}{|c|c|c|c|c|c|c|c|c|}
\hline & \multicolumn{4}{|c|}{$\mathrm{pH}\left(\mathrm{H}_{2} \mathrm{O}\right)$} & \multicolumn{4}{|c|}{$\mathrm{P}\left(\mathrm{mg} \mathrm{dm}^{-3}\right)$} \\
\hline & $0-10 \mathrm{~cm}$ & $10-30 \mathrm{~cm}$ & $30-60 \mathrm{~cm}$ & Mean & $0-10 \mathrm{~cm}$ & $10-30 \mathrm{~cm}$ & $30-60 \mathrm{~cm}$ & Mean \\
\hline Forest & 4.6 & 4.5 & 4.7 & $4.5 b$ & 7.0 & 3.8 & 2.8 & $4.5 b$ \\
\hline UT & 5.8 & 6.0 & 5.9 & $5.9 \mathrm{a}$ & 170.2 & 100.6 & 99.0 & $123.2 \mathrm{ab}$ \\
\hline MT & 6.2 & 6.3 & 6.4 & $6.3 \mathrm{a}$ & 206.2 & 174.2 & 137.2 & $172.5 \mathrm{a}$ \\
\hline$\underline{\mathrm{LT}}$ & 5.8 & 5.7 & 6.1 & $5.9 \mathrm{a}$ & 150.4 & 132.0 & 134.6 & $139.0 \mathrm{ab}$ \\
\hline Mean & $5.6 \mathrm{~A}$ & $5.6^{\mathrm{a}}$ & $5.8^{\mathrm{a}}$ & & $133.4 \mathrm{~A}$ & $102.6 \mathrm{AB}$ & $93.4 \mathrm{~B}$ & \\
\hline F Position (P) & & $26.41 * *$ & & & & $4.17 *$ & & \\
\hline F Depth (D) & & $0.26^{\mathrm{NS}}$ & & & & $4.19 *$ & & \\
\hline $\mathrm{FP} \times \mathrm{D}$ & & $0.61^{\mathrm{NS}}$ & & & & $0.94^{\mathrm{NS}}$ & & \\
\hline \multirow[t]{3}{*}{$\mathrm{CV}(\%)$} & & 14 & & & & 101 & & \\
\hline & \multicolumn{4}{|c|}{$\mathrm{MO}\left(\mathrm{g} \mathrm{kg}^{-1}\right)$} & \multicolumn{4}{|c|}{ CTC $\left(\mathrm{cmol}_{\mathrm{c}} \mathrm{dm}^{-3}\right)$} \\
\hline & $0-10 \mathrm{~cm}$ & $10-30 \mathrm{~cm}$ & $30-60 \mathrm{~cm}$ & Mean & $0-10 \mathrm{~cm}$ & $10-30 \mathrm{~cm}$ & $30-60 \mathrm{~cm}$ & Mean \\
\hline Forest & 4.1 & 3.6 & 2.9 & $3.53 \mathrm{a}$ & 13.6 & 12.9 & 12.7 & $13.08 \mathrm{a}$ \\
\hline UT & 2.6 & 1.9 & 1.6 & $2.06 \mathrm{~b}$ & 11.8 & 10.3 & 10.1 & $10.73 \mathrm{ab}$ \\
\hline MT & 2.2 & 1.6 & 1.3 & $1.72 b$ & 10.2 & 8.2 & 8.1 & $8.85 b c$ \\
\hline LT & 2.0 & 1.7 & 1.1 & $1.62 b$ & 8.9 & 8.2 & 6.5 & $7.85 \mathrm{c}$ \\
\hline Mean & $2.73 \mathrm{~A}$ & $2.22 \mathrm{~B}$ & $1.74 \mathrm{C}$ & & $11.13 \mathrm{~A}$ & $9.9 \mathrm{~B}$ & $9.35 \mathrm{~B}$ & \\
\hline F Position (P) & & $45.83 * *$ & & & & $11.31 * *$ & & \\
\hline F Depth (D) & & $59.22 * *$ & & & & $11.46^{* *}$ & & \\
\hline $\mathrm{FP} \times \mathrm{D}$ & & $0.90^{\mathrm{NS}}$ & & & & $0.78^{\mathrm{NS}}$ & & \\
\hline \multirow[t]{3}{*}{$\mathrm{CV}(\%)$} & & 45 & & & & 31 & & \\
\hline & \multicolumn{4}{|c|}{$\mathrm{Ca}\left(\mathrm{cmol}_{\mathrm{c}} \mathrm{dm}^{-3}\right)$} & \multicolumn{4}{|c|}{$\mathrm{Mg}\left(\mathrm{cmol}_{\mathrm{c}} \mathrm{dm}^{-3}\right)$} \\
\hline & $0-10 \mathrm{~cm}$ & $10-30 \mathrm{~cm}$ & $30-60 \mathrm{~cm}$ & Mean & $0-10 \mathrm{~cm}$ & $10-30 \mathrm{~cm}$ & $30-60 \mathrm{~cm}$ & Mean \\
\hline Forest & 1.11 & 1.04 & 1.12 & $1.09 \mathrm{~b}$ & 2.64 & 1.79 & 1.50 & 1.97 \\
\hline UT & 4.26 & 3.76 & 3.43 & $3.81 \mathrm{a}$ & 2.30 & 1.96 & 1.36 & 1.87 \\
\hline MT & 4.23 & 3.73 & 3.66 & $3.87 \mathrm{a}$ & 2.17 & 1.89 & 1.45 & 1.83 \\
\hline LT & 3.78 & 3.49 & 2.68 & $3.31 \mathrm{a}$ & 1.50 & 1.60 & 1.01 & 1.37 \\
\hline Mean & $3.34 \mathrm{~A}$ & $3.01 \mathrm{~B}$ & $2.72 \mathrm{~B}$ & & $2.15 \mathrm{~A}$ & $1.8 \mathrm{AB}$ & $1.33 \mathrm{~B}$ & \\
\hline F Position (P) & & $20.80 * *$ & & & & $1.59^{\mathrm{NS}}$ & & \\
\hline F Depth (D) & & $11.38 * *$ & & & & $10.29 * *$ & & \\
\hline $\mathrm{FP} \times \mathrm{D}$ & & $2.04^{\mathrm{NS}}$ & & & & $0.63^{\mathrm{NS}}$ & & \\
\hline \multirow[t]{3}{*}{$\mathrm{CV}(\%)$} & & 47 & & & & 46 & & \\
\hline & \multicolumn{4}{|c|}{$\mathrm{K}\left(\mathrm{cmol}_{\mathrm{c}} \mathrm{dm}^{-3}\right)$} & \multicolumn{4}{|c|}{$\mathrm{V}(\%)$} \\
\hline & $0-10 \mathrm{~cm}$ & $10-30 \mathrm{~cm}$ & $30-60 \mathrm{~cm}$ & Mean & $0-10 \mathrm{~cm}$ & $10-30 \mathrm{~cm}$ & $30-60 \mathrm{~cm}$ & Mean \\
\hline Forest & $0.23 \mathrm{bA}$ & $0.20 \mathrm{aA}$ & $0.18 \mathrm{bA}$ & 0.20 & 32 & 24 & 22 & $26 b$ \\
\hline UT & $1.49 \mathrm{aA}$ & $1.05 \mathrm{aA}$ & $1.38 \mathrm{aA}$ & 1.31 & 70 & 68 & 64 & $67^{\mathrm{a}}$ \\
\hline MT & $1.81 \mathrm{aA}$ & $0.65 \mathrm{aB}$ & $0.59 \mathrm{abB}$ & 1.02 & 81 & 77 & 72 & $77^{\mathrm{a}}$ \\
\hline $\mathrm{LT}$ & $1.03 \mathrm{abA}$ & $0.53 \mathrm{aA}$ & $0.50 \mathrm{abA}$ & 0.69 & 73 & 70 & 69 & $70^{\mathrm{a}}$ \\
\hline Mean & 1.14 & 0.61 & 0.66 & & $63.91 \mathrm{~A}$ & $59.82 \mathrm{AB}$ & $56.91 \mathrm{~B}$ & \\
\hline F Position (P) & & $4.82 *$ & & & & $38.80 * *$ & & \\
\hline F Depth (D) & & $11.41 * *$ & & & & $3.92 *$ & & \\
\hline $\mathrm{F} P \times \mathrm{D}$ & & $2.98 *$ & & & & $0.23^{\mathrm{NS}}$ & & \\
\hline $\mathrm{CV}(\%)$ & & 95 & & & & 37 & & \\
\hline
\end{tabular}

Means followed by the same uppercase letter in the row and lowercase letter in the column do not differ from each other by the Tukey's test $(5 \%) . \mathrm{CV}=$ coefficient of variation.

The highest values of $\mathrm{Ca}, \mathrm{K}$, and $\mathrm{V}$ for cultivated areas are due to fertilizer and corrective inputs carried out over the years of soil management in the areas, as also justified by Portugal et al. (2010). The content of $\mathrm{Mg}$ in soils cultivated with vegetables was similar to that of adjacent forests (Table 1) since farmers do not use fertilizers with this nutrient. This similarity in the contents found in soils of cultivated areas and forests shows that $\mathrm{Mg}$ contents come primarily from soil parent material.

Base saturation (V) values also tended to decrease with depth, apparently more influenced by $\mathrm{Ca}$ and $\mathrm{Mg}$ contents since $\mathrm{K}$ contents did not vary much with depth (Table 1). $\mathrm{K}$ is retained with less energy in soil colloids when compared to $\mathrm{Ca}$ and $\mathrm{Mg}$, allowing its easy movement in the soil profile (Souza et al., 2012; Duarte et al., 2013), which justifies the greater uniformity of $\mathrm{K}$ contents in the different soil layers when compared to $\mathrm{Ca}$ and $\mathrm{Mg}$, which decreased with depth.

The similarity of $\mathrm{Ca}$ and $\mathrm{Mg}$ contents in the soil at different hillside positions are in accordance with the results observed by Santos et al. (2008). However, these authors observed a tendency of a higher $\mathrm{P}$ and $\mathrm{Mg}$ accumulation in the lower part of the terrain, which was not verified in our study. On this issue, Faria et al. (2010) found that $\mathrm{Ca}$ and $\mathrm{Mg}$ contents increased with depth in soils under native Cerrado, while we observed the opposite in soils under forest (Table 1). This contrast may be associated with the great difference between Cerrado and 
forest vegetation, which should reflect in different forms of organic matter accumulation on the soil surface.

The only significant interaction between position and soil depth was observed for $\mathrm{K}$ content (Table 1). This may have occurred due to the joint action of several factors such as soil texture and water infiltration, which vary according to the different hillside positions (Lima et al., 2015). In addition, soil $\mathrm{K}$ concentration (> $0.40 \mathrm{cmol}_{\mathrm{c}}$ $\mathrm{dm}^{-3}$ ), which is considered as high (Faria et al., 2007) and its relative mobility in the soil profile (Souza et al., 2012; Duarte et al., 2013), associated with variations of organic matter content and CEC in the different soil layers (Table 1), may have been important in this interaction.

Soils have naturally a low potential to provide $\mathrm{P}$, as can be seen by its very low contents in soil forests, a characteristic attributed to the poor parent material (gneisssandstone). However, successive phosphate fertilization to meet the needs of horticultural plants justify high $P$ contents (above $100 \mathrm{mg} \mathrm{dm}^{-3}$ ) (Silva et al., 2016). The highest $\mathrm{P}$ contents found at a depth of $0-10 \mathrm{~cm}$ are from drip fertigation, which concentrates $\mathrm{P}$ in the upper soil layer where a higher vegetable root density can be found (up to $20 \mathrm{~cm}$ ), as well as its low mobility in the soil profile (Paula et al., 2016; Fink et al., 2016). Because these areas are located in the hillside, high $\mathrm{P}$ contents are agronomically and environmentally worrisome since this nutrient may be easily carried into water sources, with a potential risk of eutrophication (Reay et al., 2012; Bai et al. 2013).

The highest soil organic matter content in the forest, when compared to those of the three hillside positions (Table 1), is due to the greater plant species diversity associated with a less soil mobilization and greater carbon recycling in this environment (Portugal et al., 2010). The addition of mineral fertilizers, especially those nitrogen-based, also induces a greater soil organic matter mineralization of cultivated areas (Lima et al., 2016). In addition, the greater the soil disturbance is, the lower the OM accumulation (Portugal et al., 2010; Lima et al., 2016). At first, we could think of the hypothesis that the lower OM content below $10 \mathrm{~cm}$ in depth in the cultivated areas was due to the lower root development capacity of vegetables when compared to large-sized plants from forests, but it does not seem to be true. If this hypothesis were correct, areas cultivated with heavy, deep root system crops, as the sugarcane crop, should have a high organic matter content even below $20 \mathrm{~cm}$ deep, which was not observed in the results found by Portugal et al. (2010).

Cultivated areas may have a CEC considered as medium (5.0-10.0 $\left.\mathrm{cmol}_{\mathrm{c}} \mathrm{dm}^{-3}\right)$, while forest areas may present it high (> $10.0 \mathrm{cmol}_{\mathrm{c}} \mathrm{dm}^{-3}$ ) (Faria et al., 2007). Soil CEC of the studied areas seems to have a high OM dependence, which is evidenced by the similarity in behavior of both variables (Table 1). This dependence was also confirmed by positive and significant correlations $(\mathrm{P}<0.01)$ between CEC and OM (Table 2) in cultivation $(0.82,0.76$, and 0.88 , respectively, for depths of $0-10,10$ 30 , and $30-60 \mathrm{~cm})$ and forest areas $(0.88,0.99$, and 0.83 , respectively, for depths of $0-10,10-30$, and $30-60 \mathrm{~cm})$.

At the depths of $10-30$ and $30-60 \mathrm{~cm}$ (Table 2), P established significant $(\mathrm{P}<0.05)$ and negative correlations with $\mathrm{H}+\mathrm{Al}$ for cultivated areas $(-0.46$ and -0.52 , respectively) and positive correlations for forest areas (0.82 and 0.91, respectively). Eberhardt et al. (2008) also obtained a negative correlation between $\mathrm{P}$ and $\mathrm{H}+\mathrm{Al}$ contents. According to Fink et al. (2016), OM has a low potential to adsorb $\mathrm{P}$ as it presents essentially negative charges, unlike $\mathrm{Fe}$ (goethite and hematite) and $\mathrm{Al}$ (gibbsite) oxides, more efficient and active in $\mathrm{P}$ adsorption, especially in the $\mathrm{pH}$ range between 4.9 and 6.5 , where $\mathrm{Fe}$ and $\mathrm{Al}$ oxides exhibit positive charges, strongly attracting orthophosphate anions.

In order to identify changes in soil chemical attributes in cultivated areas with olericulture and forest, a principal component analysis (PCA) was performed (Figure 2). This analysis allows reducing the dimensions of the data in two components and, therefore, facilitates the interpretation plotted in a biplot graph (Freitas et al., 2015). PCA explained $81.07 \%$ of the total variance of the data $(60.91 \%$ in $\mathrm{PC} 1$ and $20.16 \%$ in PC2). The PC1 axis was influenced especially by the set of chemical attributes $(\mathrm{P}, \mathrm{OM}, \mathrm{Ca}, \mathrm{K}, \mathrm{V}$, and $\mathrm{pH})$, which presented negative eigenvectors. 
TABLE 2. Pearson's linear correlation coefficients between soil chemical attributes in agricultural (A) and forest (F) areas at depths of $0-10,10-30$, and $30-60 \mathrm{~cm}$.

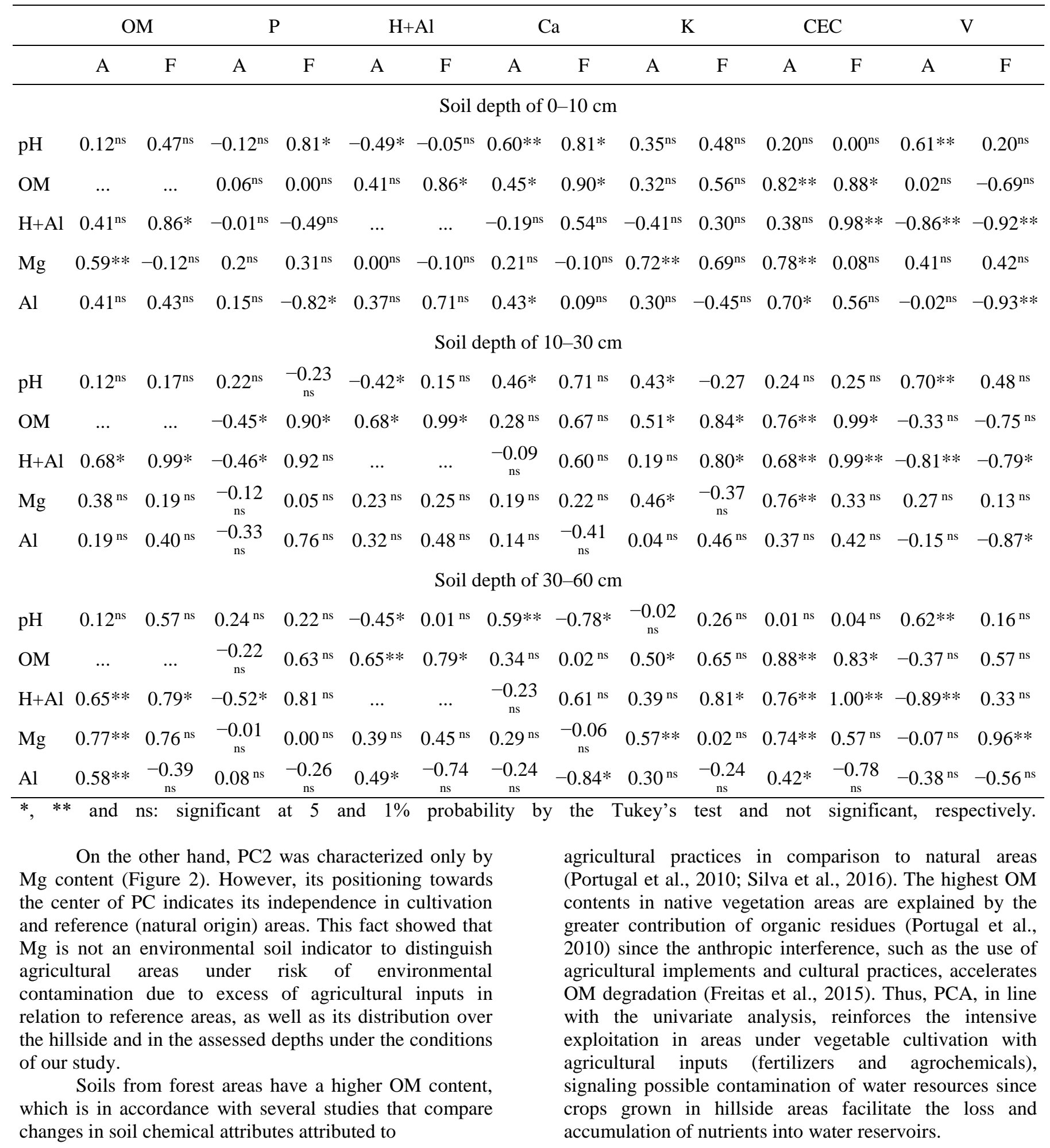




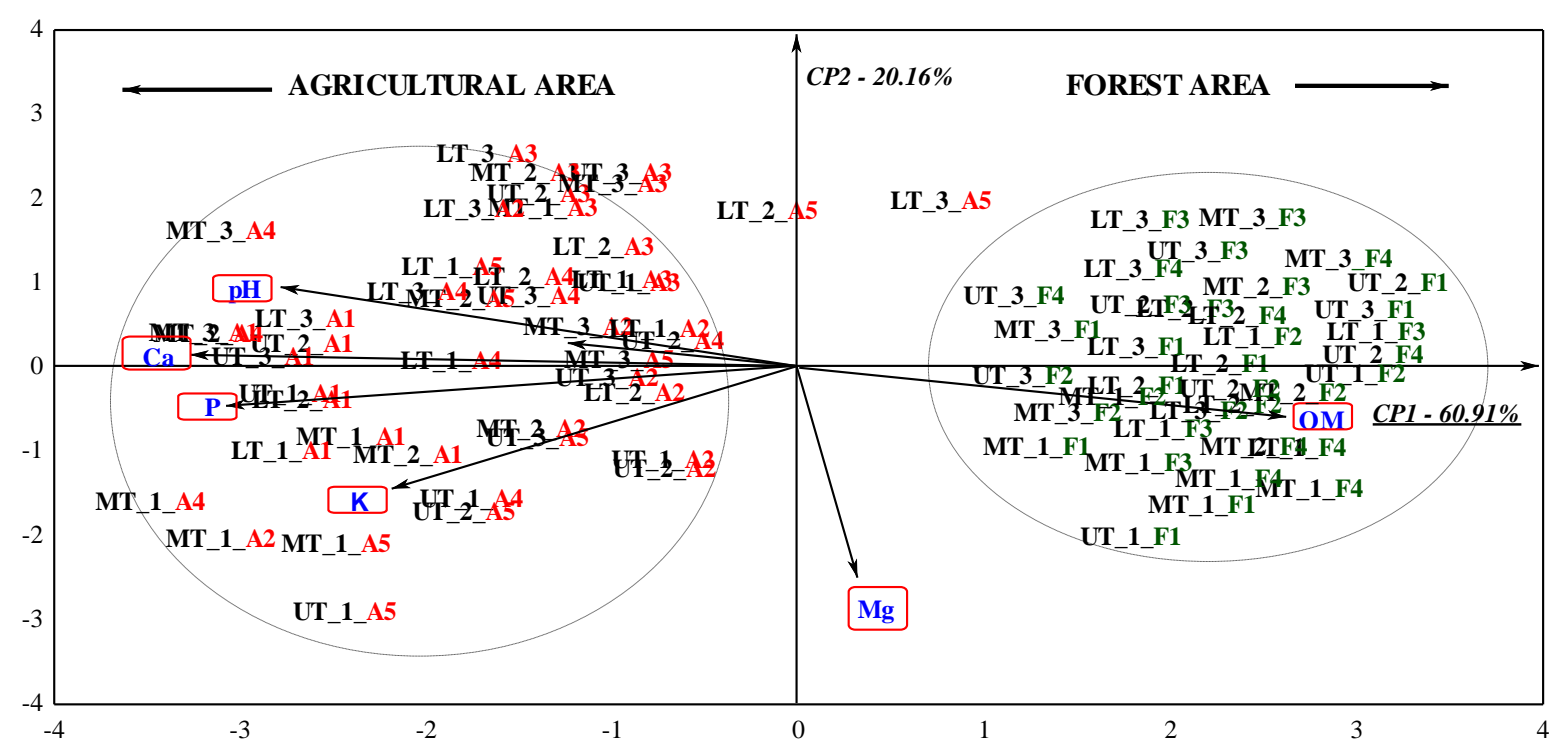

FIGURE 2: Structure of variables and distribution of samples in forest (F1, F2, F3, and F4) and agricultural (A1, A2, A3, A4, and A5) areas in the respective landscape positions (UT = upper third, MT = medium third, and LT = lower third) and depths $(1=0-10 \mathrm{~cm}, 2=10-30 \mathrm{~cm}$, and $3=30-60 \mathrm{~m})$.

Values of $\mathrm{pH}$ of water reservoirs are within the limits established by CONAMA (2005), which ranges from 6 to 9 , but a slight reduction is observed in months following increases in precipitation (Figure 3A). This variation in water $\mathrm{pH}$ may be associated with the acceleration of the eutrophication process (increase in OM, $\mathrm{Ni}$, and $\mathrm{P}$ contents), while the $\mathrm{pH}$ reduction may be associated with the surface transport and leaching of ammoniacal fertilizers (among other acid sources), being accumulated in reservoirs after higher precipitation volumes. Similar behavior was also observed in water samples from the reservoir destined to human consumption (R6), indicating that soluble organic substances may be infiltrating into the soil until reaching the water table. Duarte et al. (2008) attributed $\mathrm{pH}$ reductions to water heating and production of organic acids from the biological decomposition of water OM.
Nitrate $\left(\mathrm{NO}_{3}^{-}\right)$concentrations in water reservoirs remained below the limit of $10 \mathrm{mg} \mathrm{L}^{-1}$ (CONAMA, 2005), but an increase in concentration was observed after precipitation (Figure 3B). Water from R6 is not shown in the graph since it has a larger scale, presenting higher values for $\mathrm{NO}_{3}{ }^{-}$, ranging from 4.72 to $4.97 \mathrm{mg} \mathrm{L}^{-1}$ and with no direct relation with the precipitation of the same period. Considering that nitrate is very soluble in water and poorly adsorbed by soil (Vidal \& Neto, 2014), these results indicate that nitrate have been leached in the soil, slowly and continuously contaminating the water table over several years of infiltration since water volume in R6 is high, but variations did not respond immediately to the precipitation of the same year. The low water volumes of reservoirs and increases followed by rainy periods reveal that a small part of the nitrate from hillside soils may be being carried to dams by topsoil erosion. 

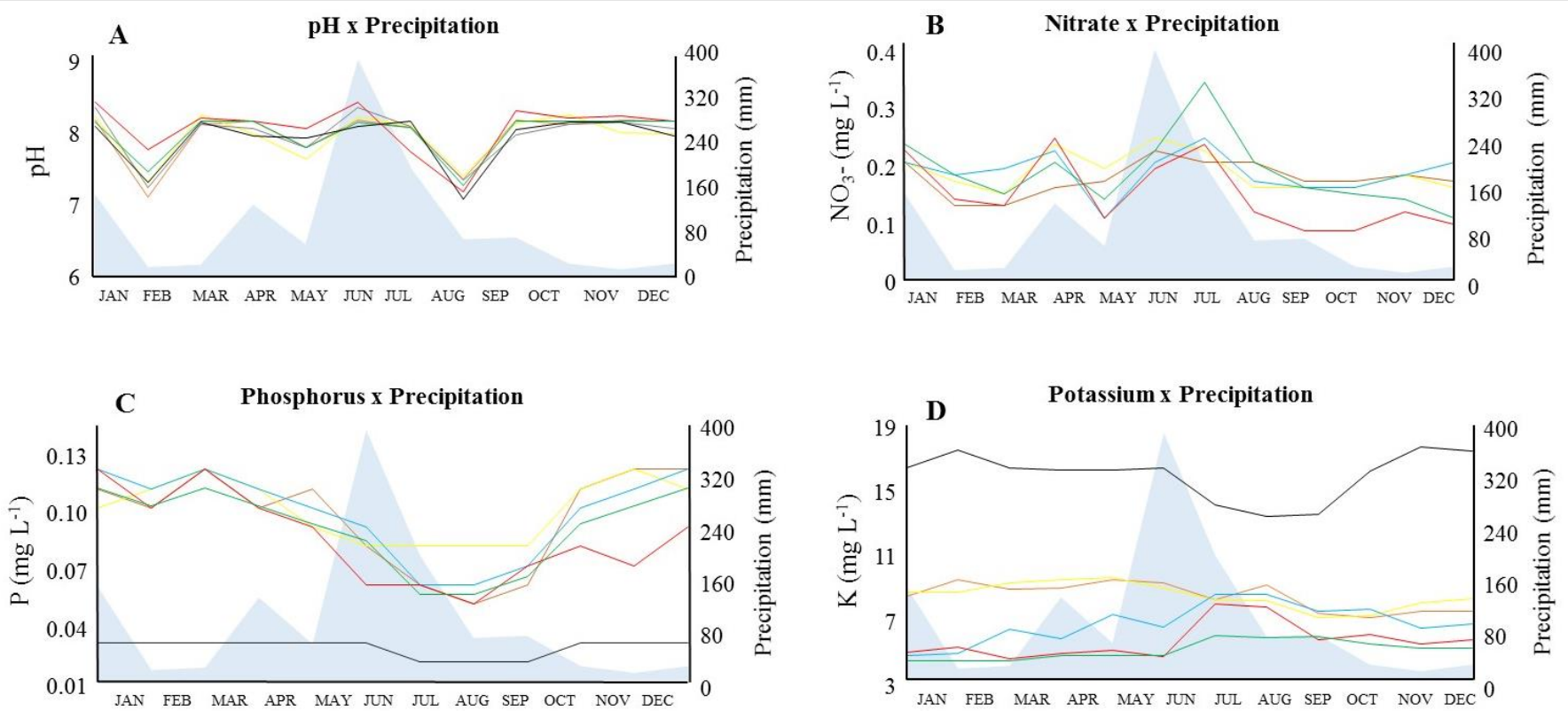

Precipitation (mm) $-\mathbf{R}-\mathbf{1}-\mathbf{R}-2-\mathbf{R}-\mathbf{3}-\mathbf{R}-\mathbf{4}-\mathbf{R}-5-\mathbf{R}-6$

FIGURE 3. Influence of precipitation and temporal variation of NPK and $\mathrm{pH}$ values on water samples from six reservoirs (R) used for vegetable irrigation (R1, R2, R3, R4, and R5) and human and animal consumption (R6) in Camocim de São Félix, PE, Brazil.

Phosphorus concentrations in dam waters (Figure $3 \mathrm{C})$ reached values $500 \%$ above the maximum of $0.02 \mathrm{mg}$ $\mathrm{L}^{-1}$ allowed by CONAMA (2005). Water from R6 had much lower $\mathrm{P}$ concentrations when compared to those from R1, R2, R3, R4, and R5, but still higher than the maximum allowed by CONAMA (2005) for human consumption. An increase in precipitation reduced $\mathrm{P}$ concentration both in water reservoirs and in R6, but the inverse was observed for $\mathrm{NO}_{3}{ }^{-}$concentration. Considering that $\mathrm{P}$ is slightly mobile in the soil (Paula et al., 2016) and that organic matter mineralization does not cause water eutrophication in these environments even in areas with high contents of this component (Freire et al., 2013; Vidal $\&$ Neto, 2014), the high concentration of $\mathrm{P}$ in reservoir waters is related to soil hillside erosion.

Potassium concentrations (Figure 3D) in all water samples from R1, R2, R3, R4, and R5 were lower than 10 $\mathrm{mg} \mathrm{L} \mathrm{L}^{-1}$, a limit value established by CETESB (1999). However, the water from R6 presented concentrations higher than $10 \mathrm{mg} \mathrm{L}^{-1}$ throughout the year. In the water destined for irrigation, $\mathrm{K}$ concentration slightly increased with the rainy period probably due to the superficial runoff of the rainwater, while in the water from R6, a reduction in $\mathrm{K}$ concentration was observed due to the dilution effect as the amount of water in the water table increased.

Souza et al. (2012) also mentioned a similarity between the temporal variations of $\mathrm{K}$ and $\mathrm{NO}_{3}{ }^{-}$contents, as observed in our study. However, because $\mathrm{K}$ is predominantly in a cationic form, it tends to be more retained by negative soil loads (Duarte et al., 2013) and, therefore, its leaching must be less intense and slower, leading to less sensitive variations than those observed for nitrate.

\section{CONCLUSIONS}

In comparison with forest areas, horticultural areas present soil with a lower organic matter content and CEC, but higher values of $\mathrm{pH}$, base saturation, and contents of $\mathrm{P}$,
$\mathrm{Ca}$, and $\mathrm{K}$.

In cultivated areas, CEC decreases from the upper to the lower hillside, without significant changes in the other parameters of soil fertility.

Water from reservoirs adjacent to the hillside areas with horticulture is more acidic and has a higher nitrate content, especially during rainy periods.

\section{REFERENCES}

Alvares CA, Stape JL, Sentelhas PC, Gonçalves JLM, Sparovek G (2013) Köppen's climate classification map for Brazil. Meteorologische Zeitschrift 22(6):711-728. DOI: https://dx.doi.org/10.1127/0941-2948/2013/0507

Bai Z, Yang X, Zhou B, Shi X, Wang B, Li D, Shen J, Chen Q, Qin W, Oenema O, Zhang F (2013) The critical soil P levels for crop yield, soil fertility and environmental safety in different soil types. Plant and Soil 372(1):27-37. DOI: https://doi.org/10.1007/s11104-013-1696-y

BRASIL - Ministério da Agricultura e Reforma Agrária (1973) Levantamento exploratório: reconhecimento de solos do Estado de Pernambuco. Rio de Janeiro, DNPEA, $55 \mathrm{p}$.

Campos MCC, Ribeiro MR, Souza VSJ, Filho MRR, Aquino RE, Oliveira IA (2013) Superfícies geomórficas e atributos do solo em uma topossequências de transição várzea-terra firme. Bioscience Journal 29(1):132-142.

Chartres CJ, Noble A (2015) Sustainable intensification: overcoming land and water constraints on food production. Food Security 7(2):235-245. DOI: https://doi.org/10.1007/s12571-015-0425-1

CETESB - Companhia de Tecnologia de Saneamento Ambiental (1999) Variáveis de qualidade e potabilidade das águas para consumo humano. CETESB. Available in: www.cetesb.sp.gov.br/agua/rios/variáveis.asp. Accessed: Sep 26, 2017. 
CONAMA - Conselho Nacional de Meio Ambiente (2005) Lei n. 357 de 17 de março de 2005. Diário Oficial da União de 18 de março de 2005. Available in: http://www.mma.gov.br/port/conama/legiabre.cfm?codlegi =459. Accessed: Jun 13, 2017.

Coletti C, Testezlaf R, Ribeiro TAP, Souza RTG, Pereira, DA (2010) Water quality index using multivariate factorial analysis. Revista Brasileira de Engenharia Agrícola e Ambiental 14(5):517-522. DOI: http://dx.doi.org/10.1590/S1415-43662010000500009

Duarte IN, Pereira HS, Korndörfer GH (2013) Lixiviação de potássio proveniente do termopotássio. Pesquisa Agropecuária Tropical 43(2):195-200.

Duarte SA, Airoldi RPS, Folegatti MV, Botrel TA, Soares TM (2008) Efeitos da aplicação de efluente tratado no solo: $\mathrm{pH}$, matéria orgânica, fósforo e potássio. Revista Brasileira de Engenharia Agrícola e Ambiental 12(3):302310. DOI: http://dx.doi.org/10.1590/S141543662008000300012

Eberhardt DN, Vendrame PRS, Becquer T, Guimarães MF (2008) Influência da granulometria e da mineralogia sobre a retenção do fósforo em Latossolos sob pastagens no cerrado. Revista Brasileira de Ciência do Solo 32(3):10091016.

EMBRAPA - Empresa Brasileira de Pesquisa Agropecuária (1997) Centro Nacional de Pesquisa Agropecuária. Manual de métodos de análises de solo. Rio de Janeiro, Embrapa, 2 ed. 212p.

EMBRAPA - Empresa Brasileira de Pesquisa Agropecuária (2013) Sistema brasileiro de classificação de solos. Brasília, Embrapa, 3 ed. 353p.

FAO - Food and Agriculture Organization of the United Nations (1990) Soil map of the world. FAO.

Faria AFGS, Santos AC, Santos TMI, Batistella Filho F (2010) Influência do manejo do solo nas propriedades químicas e físicas em topossequência na bacia do rio Araguaia, Estado do Tocantins. Revista Brasileira de Ciência Solo 34(2):517-524. DOI: http://dx.doi.org/10.1590/S0100-06832010000200025

Faria CMB, Silva MSL, Silva DJ (2007) Alterações em características de solos do submédio São Francisco sob diferentes sistemas de cultivo. Petrolina, Embrapa Semiárido, 33p.

Freire R, Bonifácio CM, Freitas FH, Schneider RM, Tavares CRG (2013) Nitrogen forms and total phosphorus in water courses: A study at Maringá stream, Paraná State. Acta Scientiarum 35(4):711-716. DOI:

https://doi.org/10.4025/actascitechnol.v35i4.14018

Freitas L, Casagrande JC, Oliveira IA, Campos MCC, Silva LS (2015) Técnicas multivariadas na avaliação de atributos de um Latossolo vermelho submetido a diferentes manejos. Revista Brasileira de Ciências Agrárias 10(1):1726. DOI: https://doi.org/10.5039/agraria.v10i1a3928

Fink JR, Inda AV, Tiecher T, Barrón V (2016) Iron oxides and organic matter on soil phosphorus availability. Ciência Agrotecnologia 40(4):369-379. DOI:

http://dx.doi.org/10.1590/1413-70542016404023016
Guareschi RF, Pereira MG, Menezes CEG, Anjos LHC, Correia MEF (2014) Atributos químicos e físicos do solo sob pastagem e estádios sucessionais de floresta estacional. Revista de la Facultad de Agronomía 113(1):47-56.

ITEP/LAMEPE - Instituto de Tecnologia de Pernambuco (2010) Posto Camocim de São Félix-PE.

Kaiser HF (1958) The varimax criterion for analytic rotation in factor analysis. Psychometrika 23(3):187-200. DOI: https://doi.org/10.1007/BF02289233

Lima CEP, Fontenelle MR, Madeira NR, Silva J, Guedes IMR, Silva LRB, Soares DC (2016) Compartimentos de carbono orgânico em um Latossolo cultivado com hortaliças em sistemas conservacionistas. Pesquisa Agropecuária Brasileira 51(4):378-387. DOI: https://doi.org/10.1590/S0100-204X2016000400011

Lima FV, Silvino GS, Melo RSSM, Lira EC, Ribeiro TS (2015) Variabilidade espacial de atributos físicos do solo em área de encosta sob processo de degradação. Revista Caatinga 28(4):53-63. DOI: https://doi.org/10.1590/1983$21252015 \mathrm{v} 28 \mathrm{n} 406 \mathrm{rc}$

Marques Júnior J, Siqueira DS, Camargo L A, Teixeira DDB, Barrón V, Torrent J (2014) Magnetic susceptibility and diffuse reflectance spectroscopy to characterize the spatial variability of soil properties in a Brazilian Haplustalf. Geoderma 219-220:63-71. DOI: https://doi.org/10.1016/j.geoderma.2013.12.007

Oliveira IA, Freitas L, Aquino RE, Casagrande JC, Campos MCC, Silva, LS (2018) Chemical and physical pedoindicators of soils with different textures: spatial variability. Environmental Earth Sciences 77(3):81. DOI: https://doi.org/10.1007/s12665-017-7216-2

Paula DT, Martins FMV, Farias VL, Siqueira DS (2016) Clay and phosphorus losses by erosion in oxisol with sugarcane residues. Engenharia Agrícola 36(6):1063-1072. DOI: http://dx.doi.org/10.1590/1809-4430eng.agric.v36n6p1063-1072/2016

Portugal AF, Costa OD’AV, Costa LM (2010) Propriedades físicas e químicas do solo em áreas com sistemas produtivos e mata na região da Zona da Mata mineira. Revista Brasileira de Ciência do Solo 34(2):575585.

Qi SS, Hao FH, Ouyang W, Cheng HG (2012)

Characterizing landscape and soil erosion dynamics under pipeline interventions in Southwest China. Procedia Environmental Sciences 13:1863-1871. DOI: https://doi.org/10.1016/j.proenv.2012.01.180

Reay DS, Davidson EA, Smith KA, Smith P, Melillo JM, Dentener F, Crutzen PJ (2012) Global agriculture and nitrous oxide emissions. Nature Climate Change 6(2):410416. DOI: http://dx.doi.org/10.1038/nclimate1458

Resende JMA, Marques Júnior J, Martins Filho MV, Dantas JS, Siqueira DS; Teixeira DB (2014) Variabilidade espacial de atributos de solos coesos do leste maranhense. Revista Brasileira de Ciência do Solo 38(4):1077-1090. DOI: http://dx.doi.org/10.1590/S0100-

06832014000400004 
Sanchez RB, Marques JR, Souza ZM, Pereira GT, Martins MVF (2009) Variabilidade espacial de atributos do solo e de fatores de erosão em diferentes pedoformas. Bragantia 68(4):1095-1103. DOI: http://dx.doi.org/10.1590/S000687052009000400030

Santos AC, Salcedo IH, Galvão SRS (2008) Relações entre uso do solo, relevo e fertilidade do solo em escala de microbacia. Revista Brasileira de Engenharia Agrícola e Ambiental 12(5):458-464. DOI:

http://dx.doi.org/10.1590/S1415-43662008000500003

Santos JT, Andrade AP, Silva IF, Silva DS, Santos EM, Silva APG (2010) Atributos físicos e químicos do solo de áreas sob pastejo na microrregião do Brejo Paraibano. Ciência Rural 40(12):2486-2492. DOI: http://dx.doi.org/10.1590/S0103-84782010001200008

Silva LS, Galindo ICL, Nascimento CWA, Gomes RP, Campos MCC, Freitas L, Oliveira IA (2016) Heavy metal contents in Latosols cultivated with vegetable crops. Pesquisa Agropecuária Tropical 46(4):391-400. DOI: http://dx.doi.org/10.1590/1983-40632016v4641587

Souza TR, Villas Bôas RL, Quaggio JA, Salomão LC, Foratto LC (2012) Dinâmica de nutrientes na solução do solo em pomar fertirrigado de citros. Pesquisa Agropecuária Brasileira 47(6):846-854. DOI: http://dx.doi.org/10.1590/S0100-204X2012000600016

Stefanoski DC, Santos GG, Marchão RL, Petter FA, Pacheco LP (2013) Uso e manejo do solo e seus impactos sobre a qualidade física. Revista Brasileira de Engenharia Agrícola e Ambiental 17(12):1301-1309.

Vidal TF, Neto JC (2014) Dinâmica de nitrogênio e fósforo em reservatório na região semiárida utilizando balanço de massa. Revista Brasileira de Engenharia Agrícola e Ambiental 18(4):402-407. DOI: http://dx.doi.org/10.1590/S1415-43662014000400007 